\title{
Keanekaragaman Gastropoda Pada Habitat Lamun Di Perairan Desa Tayando Yamtel Kecamatan Tayando Tam Kota Tual
}

\author{
Liyatin Gea $^{1^{*}}$, A.S. Khouw ${ }^{1}$, Ch. I. Tupan ${ }^{1}$ \\ ${ }^{1}$ Program Studi Ilmu Kelautan Minat Biologi Laut \\ Fakultas Pascassarjana Ilmu Kelautan dan Perikanan, Universitas Pattimura, Ambon \\ *E-mail: liyatingea72@gmail.com
}

\begin{abstract}
Abstrak: Komunitas gastropoda merupakan komponen yang penting dalam rantai makanan di padang lamun, dimana gastropoda merupakan hewan dasar pemakan detritus (detritus feeder). Penelitian keanekaragaman gastropoda pada habitat lamun di perairan Desa Tayando Yamtel Kecamatan Tam Kota Tual, dilakukan pada bulan Maret-Mei 2018, dengan menggunakan metode transek linier kuadran. Hasil pengukuran parameter lingkungan di perairan Tayando Yamtel yaitu: nilai rata-rata $\mathrm{pH}$ 8,55; DO 6,59 $\mu \mathrm{g} / \mathrm{l}$; salinitas 32,36 \%о; suhu $29{ }^{\circ} \mathrm{C}$; TDS $24,7 \mathrm{mg} / \mathrm{l}$; kecepatan arus $(0,42$ $\mathrm{m} / \mathrm{dtk}$ ) tergolong dalam arus sedang; dan kedalaman 1,5 m. Hasil penelitian gastropoda diperoleh 862 individu yang terdiri atas 15 famili dan 30 spesies gastropoda, sedangkan untuk lamun diperoleh 3 spesies yaitu Cymodocea rotundata, Cymodocea serrulata dan Thalassia hemprichii. Nilai komposisi dan kepadatan gastropoda yang tertinggi pada stasiun I didominasi oleh spesies Psedeovertagus aluco yaitu $62,73 \%$ dan 3,708 (ind $/ \mathrm{m}^{2}$ ), sedangkan pada stasiun II yaitu $28,01 \%$ dan $0,93\left(\mathrm{ind} / \mathrm{m}^{2}\right)$ dan stasiun III yaitu 38,46 \% dan 0,15 (ind $/ \mathrm{m}^{2}$ ) didominasi oleh spesies Strombus gibberulus. Berdasarkan nilai indeks ekologi gastropoda, nilai indeks keanekaragaman dan keserasian spesies termasuk dalam kategori sedang dan nilai indeks dominansi dalam kategori rendah.
\end{abstract}

\section{Kata kunci: Gastropoda, Lamun, Tayando Yamtel}

Abstract: The gastropod community is an important component in the food chain in seagrass beds, where the gastropods are the detritus feeder. Research on the diversity of gastropods in seagrass habitat in the waters of Tayando Yamtel Village, Tam City, Tual District, was conducted in March-May 2018, using the quadrant linear transect method. The results of measurements of environmental parameters in Tayando Yamtel waters are: an average $\mathrm{pH}$ of 8.55 ; DO $6.59 \mu \mathrm{g} / \mathrm{l}$; salinity $32.36 \%$; temperature of $29^{\circ} \mathrm{C}$; TDS $24.7 \mathrm{mg} / \mathrm{l}$; current velocity $(0.42 \mathrm{~m} / \mathrm{sec})$ is classified as medium current; and a depth of $1.5 \mathrm{~m}$. Gastropod research results obtained 862 individuals consisting of 15 families and 30 species of gastropods, while for seagrass obtained 3 species namely Cymodocea rotundata, Cymodocea serrulata and Thalassia hemprichii. The highest 
value of composition and gastropod density at Station I was dominated by Psedeovertagus aluco species at $62.73 \%$ and 3.708 (ind $/ \mathrm{m}^{2}$ ), while at Station II were $28.01 \%$ and 0.93 (ind $/ \mathrm{m}^{2}$ ) and Station III were $38.46 \%$ and 0.15 (ind $/ \mathrm{m}^{2}$ ) are dominated by Strombus gibberulus species. Based on the gastropod ecological index value, the index value of species diversity and harmony is included in the medium category and the index value of dominance is in the low category.

\section{Keywords: Gastropoda, Seagrass, Tayando Yamtel}

Padang lamun merupakan hamparan vegetasi yang luas dengan komponen penyusun utama tumbuhan lamun dan dapat tumbuh hampir semua tipe substrat seperti pasir, lumpur dan batuan (Romimohtarto, 2001). Komunitas gastropoda merupakan komponen yang penting dalam rantai makanan di padang lamun, dimana gastropoda merupakan hewan dasar pemakan detritus (detritus feeder) Tomascik et al (1997). Tingginya tutupan vegetasi lamun di perairan memungkinkan kehadiran berbagai biota yang berasosiasi dengan ekosistem padang lamun untuk mencari makan, tempat hidup, memijah dan tempat berlindung untuk menghindari predator (Hitalessy, dkk. 2015).

Salah satu wilayah di Maluku Tenggara yang memiliki ekosistem lamun adalah di perairan Tayando Yamtel. Tayando Yamtel merupakan salah satu perairan yang terdapat di Kecamatan Tayando Tam. Tayando Tam adalah sebuah Kecamatan di Kota Tual, Maluku Tenggara. Kecamatan Tayando Tam terletak pada $5^{\circ} 31^{\prime}-5^{\circ} 4^{\prime} \mathrm{LS}$ dan $132^{\circ} 10^{\prime}-132^{\circ} 22^{\prime}$ BT. Secara topografi Kecamatan Tayando Tam berupa dataran yang memiliki luas $69,07 \mathrm{Km}^{2}$ yang terletak pada ketinggian $0-84$ meter di atas permukaan laut (Badan Pusat Statistik (BPS) Kabupaten Maluku Tenggara, 2013). Penelitian tentang keanekaragaman gastropoda di habitat Lamun pada Perairan Tayando Yamtel belum pernah dilakukan. Penelitian sebelumnya telah dilakukan oleh Metungun (2011) di perairan Teluk Un Maluku Tenggara menemukan 14 spesies gastropoda dan 2 spesies lamun. Penelitian ini bertujuan untuk menganalisis keanekaragaman gastropoda dan tingkat kepadatan jenis gastropoda yang mendominasi pada habitat lamun di perairan desa Tayando Yamtel.

\section{METODE PENELITIAN}

Penelitian ini dilaksanakan pada bulan Maret-Mei 2018. Lokasi penelitian dapat dilihat pada gambar di bawah ini: 


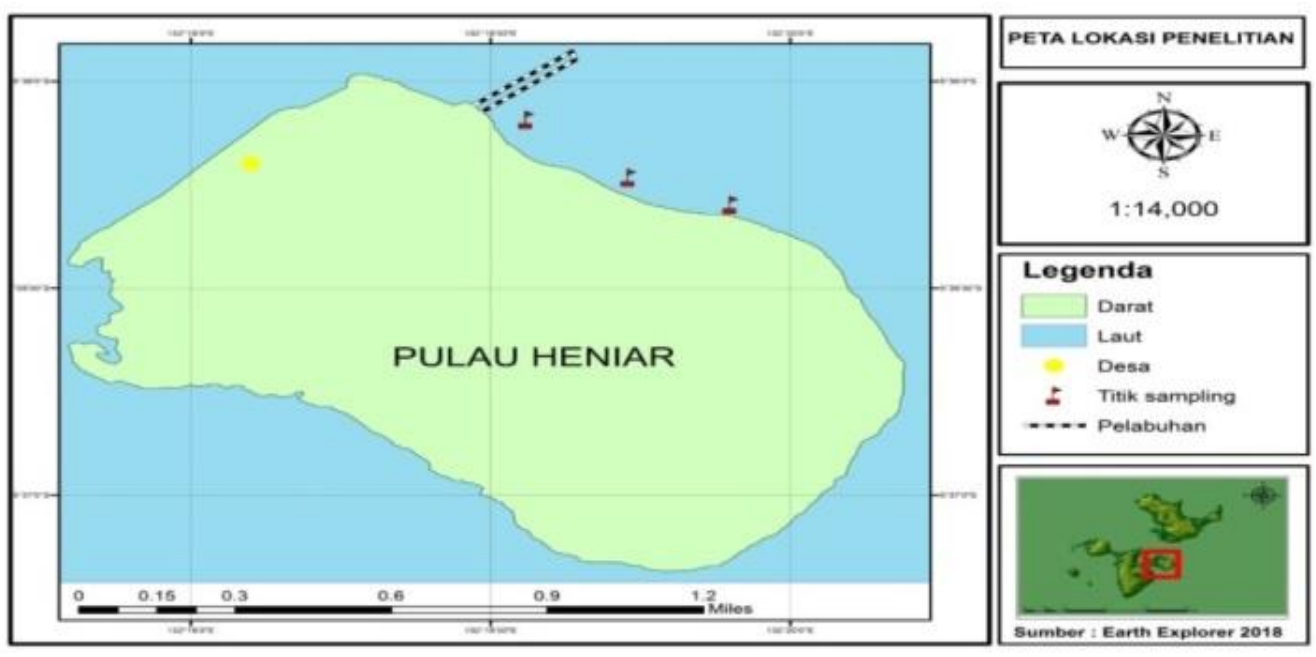

Gambar 1: Lokasi Penelitian

Alat yang digunakan antara lain kerangka kuadran PVC ukuran 50 x $50 \mathrm{~cm}$, kantong plastik, spidol, kamera, ember plastik, kantong plastik berlabel, rol meter, GPS (Global Positioning System) dan buku identifikasi gastropoda di perairan laut (Dance, 2002; Hinton 1972; Oliver, 2004). Pengukuran kualias air yaitu pH, DO, Salinitas, TDS, dan Suhu menggunakan WQC (Water Quality Chacker) Multi 3430 SET F. Tingkat kecerahan menggunakan Secchi disk dan kecepatan arus. Sedangkan bahan yang digunakan antara lain sampel gastropoda, sampel air laut, aquades, tisu, dan alkohol 70\% (mengawetkan sampel).

Pada setiap stasiun, pengambilan data menggunakan metode line transek. Meteran ditarik $100 \mathrm{~m}$ sejajar dengan garis pantai dan $100 \mathrm{~m}$ tegak lurus kearah laut tepat di area hamparan lamun. Sebanyak 100 kuadran pada setiap stasiun dan diletakkan pada areal tersebut. Selanjutnya pada setiap kuadran diambil sampel gastropoda, baik yang menempel di daun lamun, di atas sedimen, dan yang ada di dasar substrat, kemudian langsung dimasukan ke dalam plastik sampel yang sudah di isi alkohol $70 \%$ lalu di beri label. Kemudain sampel tersebut diidentifikasi di Laboratorium LIPI kota Tual. Pengukuran kualitas perairan, yaitu pH, DO, Salinitas, TDS, dan Suhu menggunakan WQC (Water Quality Chacker) Multi 3430 SET F dengan cara mencelupkan batang elektoda ke dalam perairan. Tingkat kecerahan menggunakan Secchi disk dan kecepatan arus menggunakan bola pimpong.

\section{Kepadatan dan Komposisi Gastropoda}

Kepadatan didefinisikan sebagai jumlah individu per satuan luas atau volume (Brower and Zar, 1977 dalam Rasyid, 2001) dengan rumus sebagai berikut :

$$
D=\frac{\Sigma n i}{A}
$$


Keterangan:

D: Kepadatan (ind $/ \mathrm{m}^{2}$ )

ni:Jumlah individu Gastropoda yang ditemukan

A: Jumlah kuadran pengambilan Gastropoda contoh $\left(\mathrm{m}^{2}\right)$

Komposisi gastropoda pada masing-masing stasiun dihitung dengan menggunakan rumus sebagai berikut (Brower and Zar, 1977 dalam Rasyid, 2001) :

$$
P i=\frac{\Sigma n i}{N} \times 100 \%
$$

Keterangan :

Pi: Presentase gastropoda kelas ke-i;

$\mathrm{Ni}$ : Jumlah jenis gastropoda kelas ke-i;

$\mathrm{N}$ : Jumlah total jenis gastropoda

\section{Keanekaragaman, Keseragaman, Dominansi}

Adapun indeks keanekaragaman yang digunakan adalah Indeks keanekaragaman Shannon (Khouw, 2016), dengan formula:

Dimana:

$$
\mathrm{H}^{\prime}=-\sum p i \ln p i \text { dengan } p i=\frac{n i}{N}
$$

H': Indeks Shannon

$\mathrm{N}$ : Total jumlah individu semua spesies

$\mathrm{n}_{\mathrm{i}}$ : Jumlah individu spesies ke $-\mathrm{i}$

ln: Logaritma natural $\left(2.302585 \log _{10}=0.693147\right.$

Rumus indeks keseragaman Odum (1983), yaitu:

Dimana :

$$
E=\frac{H^{\prime}}{\ln S}
$$
E: Indeks Keseragaman
H': Indeks Keanekaragaman
S: Jumlah Jenis.

Rumus indeks dominansi Simpson (C) menurut Pielou (1969) dalam (Khouw, 2016) yaitu :

$$
C=\Sigma \frac{n i(n i-1)^{\prime}}{N(N-1)}
$$

Dimana:

C: Indeks dominansi Simpson

ni: Jumlah individu spesies ke-i

BIOLOGI SEL (VOL 9 NO 2 EDISI JUL-DES 2020 ISSN 2252-858X/E-ISSN 2541-1225) PAGE 166 
$\mathrm{N}$ : Jumlah individu seluruh jenis

\section{HASIL DAN PEMBAHASAN}

\section{Kualitas Perairan Lokasi Penelitian}

Hasil pengukuran parameter kualitas perairan di desa Tayando Yamtel dapat dilihat pada gambar 2 berikut ini:

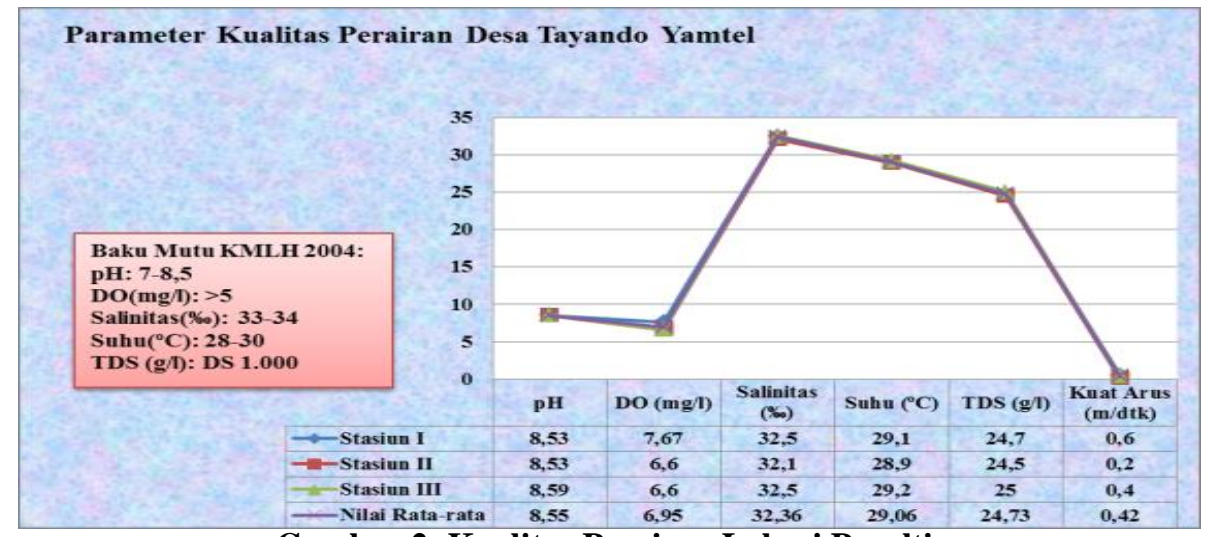

Gambar 2: Kualitas Perairan Lokasi Peneltian

Berdasarkan gambar diatas, nilai $\mathrm{pH}$ berkisar 8,53-8,59 dengan nilai rata-rata $\mathrm{pH}$ 8,55; Nilai ini merupakan kisaran yang normal bagi $\mathrm{pH}$ air laut Indonesia, dimana menurut Nontji (2002) bahwa kisaran yang normal untuk perairan Indonesia berkisar 6,0-8,5. Menurut Odum (1996) dalam Satria (2014), bahwa Gastropoda umumnya membutuhkan $\mathrm{pH}$ air antara 6,5-8,5 untuk kelangsungan hidup dan reproduksi. Nilai DO berkisar antara $6,60 \mu \mathrm{g} / 1-7,67 \mu \mathrm{g} / 1$ dengan rata-rata $6,59 \mu \mathrm{g} / \mathrm{l}$. Kisaran nilai DO yang diperoleh jika dibandingkan dengan standar baku mutu KEPMENLH No 51 Tahun 2004 masih dapat ditolerir untuk kehidupan gastropoda dan lamun.

Nilai salinitas berkisar 32,1\%o.- 32,5\% dengan rata-rata 32,36 \%o. Nilai salinitas optimum untuk spesies lamun adalah $35 \%$ (Dahuri, 2003). Menurut Dharmawan (1995) dalam Satria (2014) salinitas yang optimal untuk kehidupan gastropoda berada pada kisaran 28-34\%o. Kondisi nilai salinitas di perairan ini masih dalam kondisi baik untuk biota laut, karena masih dalam ambang batas baku mutu air laut yaitu 33-34 \%o (KLMH, 2004).

Nilai suhu berkisar $28,9-29,2^{\circ} \mathrm{C}$ dengan nilai rata-rata suhu $29{ }^{\circ} \mathrm{C}$. Menurut Sukarno (1981) dalam Ira, et. al. (2014) bahwa suhu dapat membatasi sebaran hewan gastropoda secara geografik dan suhu yang baik untuk pertumbuhan gastropoda berkisar antara $25-31^{\circ} \mathrm{C}$. Berdasarkan kriteria baku mutu air laut, nilai suhu yang diperoleh pada perairan ini masih dalam kondisi baik untuk biota laut yaitu 28-30 ${ }^{\circ} \mathrm{C}$ (KLMH, 2004).

Nilai kisaran TDS sebesar 24,5 mg/l - 25,0 mg/l dengan nilai rata-rata sebesar $24,7 \mathrm{mg} / \mathrm{l}$. Tingginya nilai TDS dapat menyebabkan terganggunya pertumbuha karang dan biota laut disekitarnya hal ini bisa terjadi apabila dalam suatu perairan memiliki 
tingkat kekeruhan yang tinggi (Mukhtasor, 2007 dalam Pratama, 2018). Berdasarkan kriteria baku mutu air laut untuk biota laut, nilai TDS yang diperoleh pada periaran ini masih dalam kondisi baik, karena masih dalam ambang batas yaitu TDS $1000 \mathrm{mg} / \mathrm{L}$ (KLMH, 2004).

Kecepatan arus berkisar pada nilai $(0,6-0,2 \mathrm{~m} / \mathrm{dtk})$ dengan nilai rata-rata $(0,42$ $\mathrm{m} / \mathrm{dtk}$ ) menunjukan tergolong dalam arus rendah. Sebagaimana menurut Mason (1981), pengelompokan kecepatan arus dengan nilai kisaran $0,25-0,5 \mathrm{~m} / \mathrm{dtk}$ adalah berarus sedang. Hal ini disebabkan karena ekosistem padang lamun di perairan pada lokasi penelitian berada di tengah-tengah antara ekosistem mangrove dan ekosistem terumbu karang.

Kedalaman perairan di pantai pada lokasi penelitian berkisar antara $\pm 1- \pm 2 \mathrm{~m}$ dengan nilai rata-rata 1,5 m. Berdasarkan KMLH No 51 Tahun 2004, kriteria baku mutu air laut untuk biota laut yaitu tingkat kecerahan yang baik untuk pertumbuhan lamun dengan kedalaman $\geq 3 \mathrm{~m}$. Pada daerah yang dalam tingkat kecerahan menentukan mutu perairan sebagai daerah asuhan bentos pada tingkat kedalaman 15-40 meter masih tergolong baik sebagai habitat makrozoobentos termasuk gastropoda (Hutabarat dan Evans, 2000).

\section{Komposisi dan Kepadatan Spesies Gastropoda}

Hasil penelitian menunjukan bahwa gastropoda yang ditemukan dilokasi penelitian terdiri atas 862 individu yang terdiri atas 15 famili dan 30 spesies Gastropoda. Pada stasiun I ditemukan 491 individu yang terdiri atas 12 famili dan 22 spesies. Pada stasiun II jenis gastropoda ditemukan 332 individu yang terdiri atas 10 famili dan 21 spesies. Jenis Gatropoda pada stasiun III ditemukan 39 individu yang terdiri atas 5 famili dan 10 spesies. Spesies Gastropoda yang paling banyak ditemukan berasal dari famili Strombidae dan Cypracidae dengan jumlah jenis sebanyak 5 spesies. Selanjutnya dari famili Cerithiidae ditemukan jumlah spesies sebanyak 4 spesies, dari famili Nassariidae sebanyak 3 spesies, dari famili Conidae dan Neritidae sebanyak 2 spesies. Sedangkan famili dengan jumlah spesies terendah ditemukan pada Muricidae, Vasidae, Trochidae, Volutidae, Littorinidae, Buccinidae, Costellariidae, Columbellidae dan Mitradae masing-masing sebanyak 1 spesies.

Komposisi spesies gastropoda untuk masing-masing stasiun dapat dilihat pada gambar 3 berikut ini: 


\section{JURNAL BIOLOGY SCIENCE \& EDUCATION 2020 LYYATIN GEA, DKK}
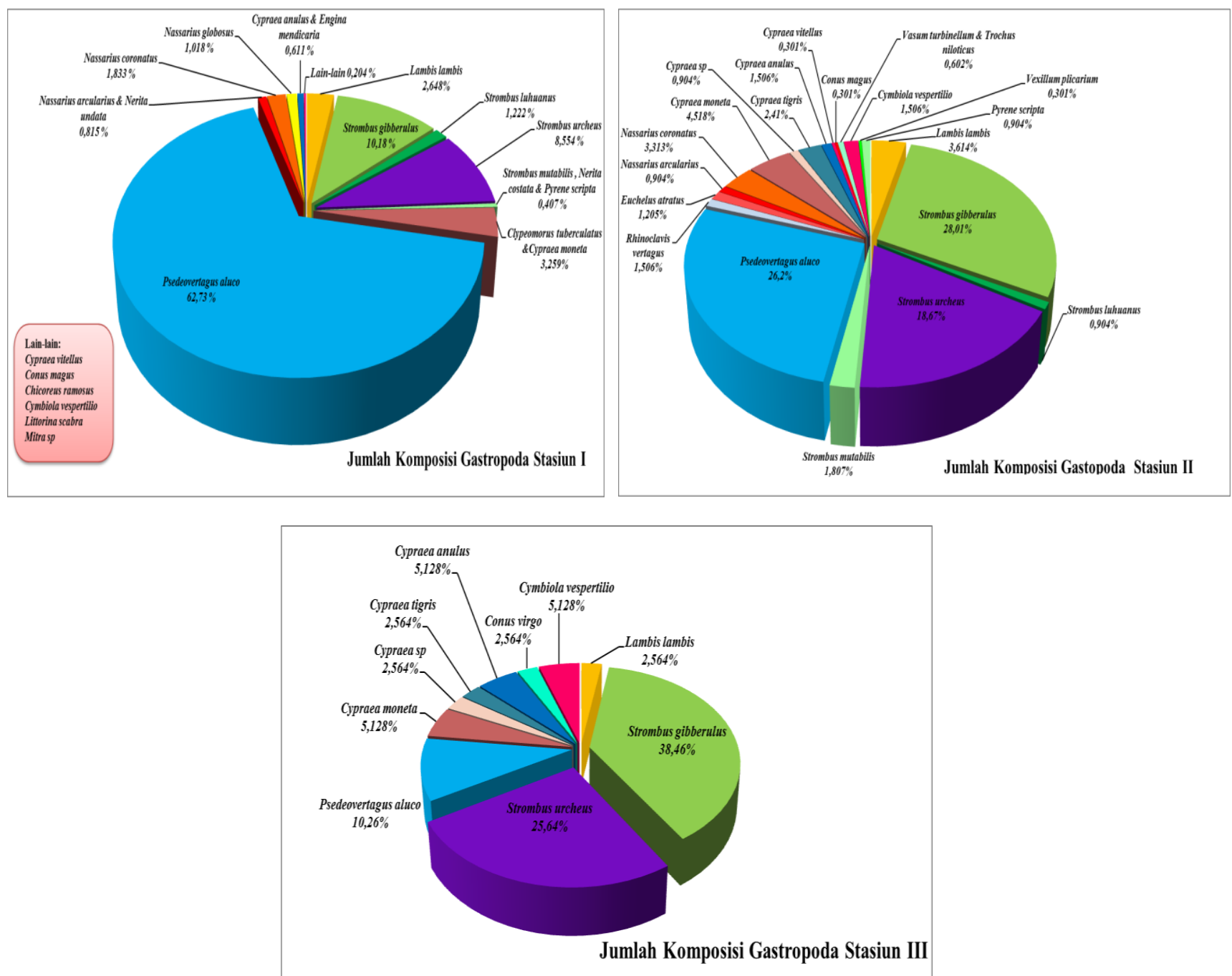

Gambar 3: Jumlah Komposisi Gastropoda pada Habitat Lamun Di setiap Stasiun

Hasil hitung nilai rata-rata kepadatan gastropoda di lokasi penelitian dapat dilihat pada gambar 4 berikut. 

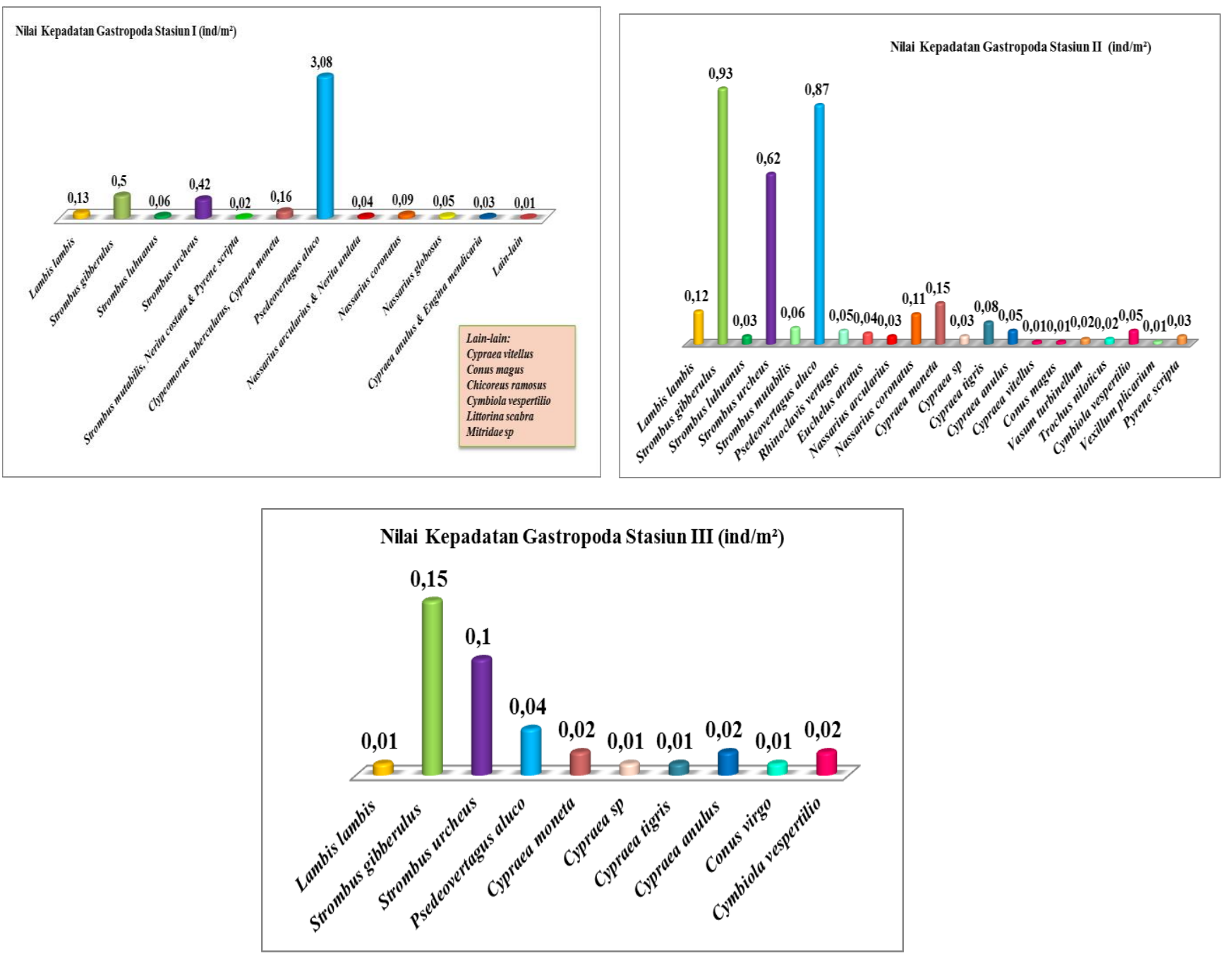

Gambar 4: Nilai Kepadatan Gastropoda Di Setiap Stasiun

Berdasarkan gambar 3 dan 4, jumlah komposisi gastropoda dan kepadatan gatropoda yang tertinggi pada stasiun I adalah spesies Psedeovertagus aluco yaitu 62,73 $\%$ dan 3,708 (ind $/ \mathrm{m}^{2}$ ) dengan jumlah individu 308 dan komposisi gastropoda dan kepadatan gatropoda yang terendah adalah spesies Cypraea vitellus, Conus magus, Chicoreus ramosus, Cymbiola vespertilio, Littorina scabra, dan Mitra sp dengan jumlah komposisi masing-masing sebesar 0,204\% dan 0,01 (ind/ $\mathrm{m}^{2}$ ) dengan jumlah individu 1 . Jumlah komposisi gastropoda dan kepadatan gastropoda yang tertinggi pada stasiun II yaitu $28,01 \%$ dan $0,93\left(\mathrm{ind} / \mathrm{m}^{2}\right)$ dan III yaitu $38,46 \%$ dan $0,15\left(\mathrm{ind} / \mathrm{m}^{2}\right)$ didominasi oleh spesies Strombus gibberulus. Sedangkan jumlah komposisi gastropoda dan kepadatan gastropoda yang terendah pada stasiun II adalah spesies Cypraea vitellus, Conus magus dan Vexillum plicarium dengan jumlah komposisi masing-masing sebesar 
$0,301 \%$ dan 0,01 (ind $/ \mathrm{m}^{2}$ ) dengan jumlah individu 1. Jumlah kompsisi gastropoda dan kepadatan gastropoda yang terendah pada stasiun III adalah spesies Lambis lambis, Cypraea sp, Cypraea tigris dan Conus virgo dengan jumlah komposisi gastropoda masing-masing sebesar $2,564 \%$ dan 0,01 (ind $/ \mathrm{m}^{2}$ ) dengan jumlah individu 1 .

Hasil penelitian spesies gastropoda Psedeovertagus aluco ditemukan atas dasar substrat dan didalam substrat juga berada pada daun tumbuhan lamun. Komposisi spesies tertinggi ini juga diduga karena spesies tersebut telah mampu beradaptasi dan cocok hidup pada lingkungan tersebut. Hal ini menunjukkan bahwa spesies tersebut mempunyai kisaran yang cukup luas terhadap faktor lingkungan, mampu berkembang biak dengan cepat dan disebabkan oleh cara penyebaran yang luas serta mempunyai jelajah yang digunakannya untuk mencari dan memanfaatkan sumber daya yang diperlukan.

Gastropoda spesies Psedeovertagus aluco memiliki jumlah individu, komposisi spesies dan kepadatan yang tinggi pada stasiun I disebabkan karena spesies tersebut memiliki habitat yang hidup di daerah sekitaran padang lamun yang membuat jenis tersebut mendapatkan konsumsi oksigen terlarut yang baik, terutama dalam bentuk anakan Psedeovertagus aluco ditemukan menempel pada daun tumbuhan lamun $C$. rotundata pada stasiun I lebih banyak dibandingkan dengan stasiun II dan III. Sehingga membuat pertumbuhan dan proses reproduksi spesies tersebut juga baik.

Sedangkan spesies gastropoda dengan jumlah individu, komposisi spesies dan kepadatan gastropoda yang tertinggi pada stasiun II dan III adalah spesies Strombus gibberulus selain ditemukan pada atas substrat dan didalam substrat kadang ditemukan berada diatas daunan lamun $C$. serrulata dan T. Hemprichii. Sebagaimana menurut Budiman (1991) dalam Ira, et. al. (2014) bahwa kekayaan spesies moluska di suatu habitat sangat bergantung pada kemampuan spesies untuk beradaptasi terhadap kondisi lokal dan jumlah tipe habitat didalam ekosistem yang dapat mengakomodasi spesies untuk hidup baik. Keberadaan Strombus gibberulus yang tinggi pada staiun II dan III diasumsikan karena kemampuan beradaptasi dengan berbagai spesies substrat dengan kondisi perairan yang baik menunjukkan bahwa dapat hidup dengan baik.

Rendahnya spesies Cypraea vitellus, Conus magus, Chicoreus ramosus pada stasiun I dan II, Cymbiola vespertilio, Littorina scabra, Mitra sp pada stasiun I dan Vexillum plicarium pada stasiun II, Lambis-lambis, Cypraea sp, Cypraea tigris dan Conus virgo pada stasiun III di padang lamun karena memanfaatkan tumbuhan lamun bukan sebagi sumber makanan melainkan dimanfaatkan sebagai habitat tempat hidup. Hal ini terjadi karena umumnya biota gastropoda memanfaatkan bahan organik disubstrat sebagai makanan melalui sistem penyaringan makanan atau dikenal sebagai filter feeder. Permukaan substrat diduga memiliki kandungan bahan organik yang lebih tinggi dibandingkan dengan bebatuan sehingga sebagian besar spesies gastropoda hidup 
pada permukaan substrat. Kondisi padang lamun yang kompleks dapat dimanfaatkan oleh moluska sebagai tempat peletakkan telur (Huang, 2010 dalam Islami, 2009).

Salah satu faktor rendahnya spesies gastropoda adalah bentuk cangkang yang indah seperti spesies Conus, Cypraea vitellus, Cypraea sp, Cypraea tigris, Cymbiola vespertilio,Chicoreus ramosus Lambis-lambis sehingga keberadaannya di buru oleh diantara para kolektor cangkang siput laut (Monteiro, 1999 dalam Islami, 2009). Rendahnya spesies Littorina scabra disebabkan karena merupakan organisme yang dominan pada ekosistem magrove bukan pada ekosistem lamun. Spesies gastropoda ini ditemukan pada lokasi penelitian karena padang lamun ini berada dikawasan daerah mangrove, sehingga keberadaanya di padang lamun sedikit.

Menurut Romimohtarto dan Juwana (2001) dalam Hartoni dan Andi (2012) mengatakan Littoria scabra merupakan organisme yang dapat hidup di batang, daun dan tangkai mangrove dan gastropoda ini dapat hidup di mintakat air pasang dan tahan kekeringan karena dapat menutup rapat cangkangnya dan menggunakan air didalamnya. Sedangkan Mitra sp dan Vexillum plicarium hidup di daerah berbatu dan jarang ditemukan. Sebagaimana menurut Budiman (1991) dalam Ira, et. al. (2014) bahwa kekayaan jenis moluska di suatu habitat sangat bergantung pada kemampuan spesies untuk beradaptasi terhadap kondisi lokal dan jumlah tipe habitat didalam ekosistem yang dapat mengakomodasi spesies untuk hidup baik.

\section{Indeks Keanekaragaman, Keseragaman, Dominansi Gastropoda}

Berdasarkan hasil hitung, nilai indeks keanekaragaman, keseragaman dan dominansi gastropoda di lokasi penelitian dapat dilihat pada gambar 5 berikut.

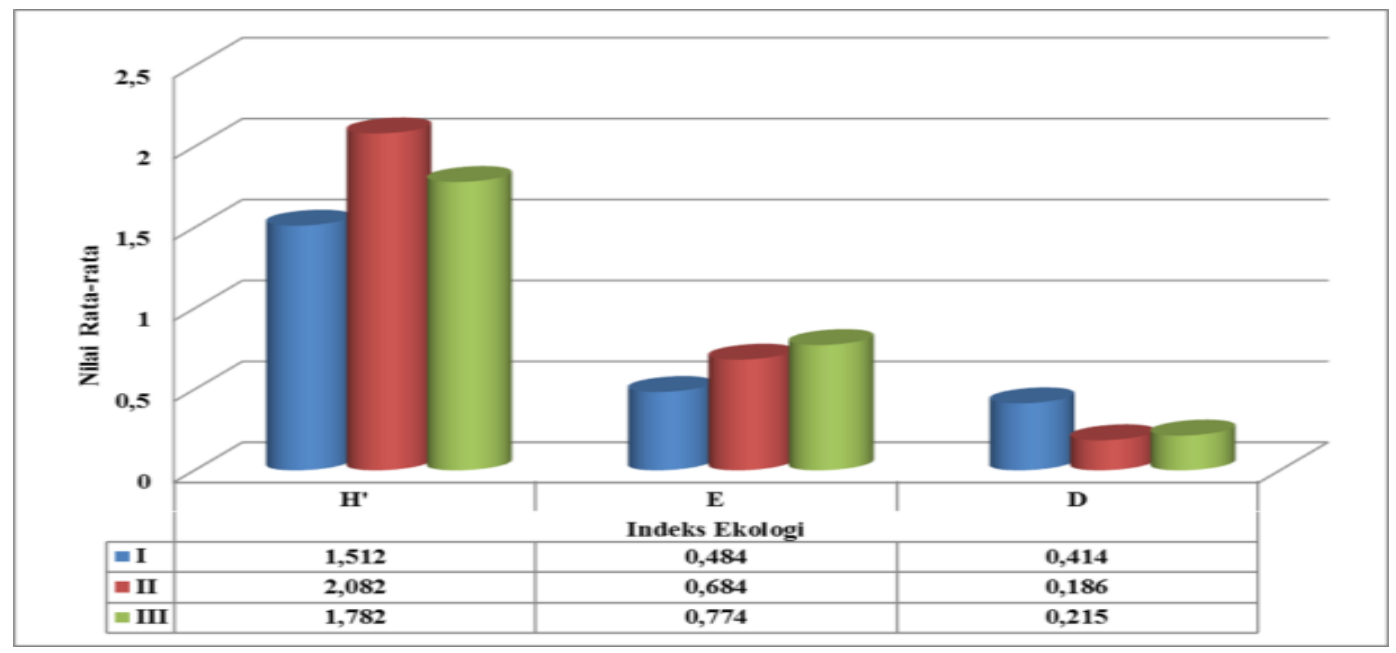

Gambar 5: Nilai Indeks Ekologi Gastropoda pada Setiap Stasiun

Nilai indeks keanekaragaman (H') sesuai kriteria yang ditetapkan Shanon Wiener untuk indeks keanekaragaman yang menyatakan, jika nilai $\mathrm{H}<1$ maka tingkat keanekaragamannya kecil, $1<\mathrm{H} ` 3$ masuk dalam kategori sedang dan $\mathrm{H}^{`}>3$ tergolong dalam kategori keanekaragaman tinggi Fachrul (2007). Dengan demikian maka nilai 
indeks keanekaragaman gastropoda pada ketiga stasiun tersebut tergolong sedang. Hal ini dikarenakan kualitas parameter perairan masih dalam keadaan normal dan baik serta mempunyai tipe substrat yang beragam mendukung dan baik bagi gastropoda. Menurut Odum, (1971) menyatakan bahwa jenis substrat dasar merupakan komponen yang sangat penting bagi kehidupan organisme benthos. Salah satu penyebab indeks keanekaragaman gastropoda sedang pada daerah padang lamun perairan desa Tayando Yamtel, adanya aktifitas masyarakat terhadap pengambilan gaastropoda secara terusmenerus, baik untuk kepentingan komersil maupun untuk dikonsumsi. Sehingga menurunkan kualitas jumlah dan spesies gastropoda.

Nilai indeks keseragaman (E) berkisar antara 0 dan 1. Jika nilai E mendekati 1 maka menggambarkan suatu keadaan dimana semua spesies cukup melimpah (keseragaman seimbang). Sedangkan jika nilai E mendekati 0 maka keseragaman jenis spesies tidak seimbang. Menurut Odum (1983) nilai indeks keseragaman $0,0<\mathrm{E} \leq 0,50$ adalah tertekan, berkisar $0,50<\mathrm{E} \leq 0,75$ adalah labil, nilai indeks $0,75<\mathrm{E} \leq 1,0$ adalah stabil. Berdasarkan hasil analisis data gastropoda di padang lamun, menunjukkan nilai keseragaman berada pada kisaran 0,48-0,77, dengan demikian kondisi keseragaman terkategorikan sedang dan kondisi ekosistem pada stasiun I $(0,489)$ kurang stabil, sedangkan stasiun II $(0,684)$ dan stasiun III $(0,774)$ dengan kondisi ekosistem stabil.

Menurut Natan dan Khouw (2002) nilai keserasian spesies yang rendah menunjukan adanya ketidakstabilan komunitas akibat tekanan faktor-faktor lingkungan seperti makanan dan adaptasi. Komunitas yang stabil artinya penyebaran individu relatif sama atau seragam. Adanya kondisi lingkungan yang relatif seragam memungkinkan seimbangnya penyebaran spesies gastropoda di seluruh perairan dangkal desa Tayando Yamtel. Menurut Hemminga dan Duarte (2000) dalam Deviana (2014), kerapatan daun dan struktur penutupan lamun juga berpengaruh terhadap keseimbangan penyebaran gastropoda.

Odum (1983) menyatakan bahwa kisaran nilai indeks dominansi Simpson adalah 0 sampai dengan 1 dengan kriteria jika $0,0<\mathrm{C} \leq 0,50$ maka dominansi rendah, jika 0,50 $<\mathrm{D} \leq 0,75$ maka Dominansi sedang dan jika $0,75<\mathrm{D} \leq 1,00$ maka dominansi tinggi. Dengan kriteria tersebut maka nilai indeks dominansi pada lokasi penelitian berkisar antara 0,186-0,414 yaitu stasiun I sebesar 0,414, stasiun II sebesar 0,186 dan stasiun III sebesar 0,215 dengan kategori rendah. Dengan demikian bahwa tidak ada spesies tertentu yang mendominasi perairan meskipun ditemukan ada beberapa spesies yang muncul dalam jumlah yang banyak.

Nilai dominansi tergolong rendah dikarenakan dari 22 spesies gastropoda yang ditemui pada stasiun I hanya terdapat 2 spesies gastropoda yang memiliki nilai kepadatan tinggi dan berbeda jauh nilai kepadatan dari 20 spesies lainnya. Pada stasiun II dari 21 spesies terdapat 5 spesies yang memiliki kepadatan tinggi daripada nilai kepadatan 16 spesies yang lainnya. Sedangkan pada stasiun III dari 10 spesies terdapat 
4 spesies yang nilai kepadatan tinggi daripada nilai kepadatan 6 spesies yang lainnya. Semakin besar nilai indeks semakin besar kecenderungan salah satu spesies mendominasi populasi.

Suatu komunitas mempunyai keanekaragaman spesies tinggi jika komunitas itu tersusun oleh banyak spesies dengan kelimpahan spesies yang sama. Sebaliknya jika komunitas itu tersusun oleh sangat sedikit spesies, dan jika hanya sedikit saja spesies yang dominan, maka keanekaragamannya rendah (Soegianto, 1994).

\section{KESIMPULAN}

Berdasarkan hasil penelitian, maka dapat disimpulkan bahwa jenis dan tingkat kepadatan gastropoda di perairan Desa Tayando Yamtel mulai dari yang tertinggi hingga terendah yaitu masing-masing pada stasiun I memiliki 22 jenis gastropoda, dengan kepadatan tertinggi jenis Psedeovertagus aluco dan terendah jenis Cypraea vitellus, Conus magus, Chicoreus ramosus, Cymbiola vespertilio, Littorina scabra, dan Mitra sp. Pada stasiun II memiliki 21 jenis gastropoda dengan kepadatan tertinggi jenis Strombus gibberulus dan yang terendah jenis Cyp.vitellus, C.magus, dan Vexillum plicarium. Sedangkan pada stasiun III ditemukan 10 jenis gastropoda dengan kepadatan tertinggi jenis Strombus gibberulus dan yang terendah jenis Lambis lambis, Cyp sp, Cyp.tigris, dan C.virgo. Berdasarkan nilai indeks ekologi gastropoda, nilai indeks keanekaragaman dan keserasian spesies termasuk dalam kategori sedang dan nilai indeks dominansi dalam kategori rendah.

\section{SARAN}

Perlu adanya penelitian mengenai karakterisitk substrat atau tipe substrat yang mempengaruhi struktur komunitas dan asosiasi gastropoda pada habitat lamun.

\section{DAFTAR PUSTAKA}

Badan Pusat Statistik (BPS) Kabupaten Maluku Tenggara. (2013). Tayando Tam Dalam Angka 2013.

Dahuri, R. (2003). Keanekaragaman Hayati Laut; Aset Pembangunan Berkelanjutan Indonesia. PT Gramedia Pustaka Utama, Jakarta.

Dance, S. Peter. (2002). Shells The clearest recognition guides available. Smithsonian Handbooks Published in the United States by Dorling Kindersley Limited, London

Deviana, Marwa. (2014). Biodiversitas Gastropoda Di Padang Lamun Perairan Balangdatu Pulau Tanakeke Kabupaten Takalar Sulawesi Selatan. Submit To J Bioslogos. Jurusan Biologi Fakultas Matematika dan Ilmu Pengetahuan Alam Universitas Hasanuddin, Makassar

Fachrul, M.F. (2007). Metode Sampling Ekologi. Bumi Aksara: Jakarta. 
Hartoni dan Andi. (2012). Komposisi dan Kelimpahan Moluska (Gastropoda dan Bivalvia) di Ekosistem Mangrove Muara Sungai Musi Kabupaten Banyuasin Provinsi Sumatera Selatan. Maspari Journal, 2013, 5(1), 6-15.

Hinton, Alan. (1972). Shells of New Guinea and the Central Indo-Pacific. Fisrt Edition. Publisher; Jacaranda Pres.

Hitalessy, R.B., Leksono, S.A dan Herawati, H.Y. (2015). Struktur Komunitas Dan Asosiasi Gastropoda Dengan Tumbuhan Lamun di Perairan Pesisir Lamongan Jawa Timur. J-PAL, Vol. 6, No. 1, 2015. ISSN: 2087-3522 E-ISSN: 2338-1671. Hal: 65.

Hutabarat, S dan S. M. Evans. (2000). Pengantar Oseanografi, Universitas IndonesiaPress, Jakarta.

Ira, et. al. (2014). Keanekaragaman Dan Kepadatan Gastropoda Di Perairan Desa Morindino Kecamatan Kambowa Kabupaten Buton Utara. Aquasains (Jurnal Ilmu Perikanan Dan Sumberdaya Perairan).

Islami, M.M. (2009). Conotoxin: Senjata utama Conus (Gastropoda: Conidae) dalam melumpuhkan mangsa. Oseana. Vol 34 (2): 33 - 40.

Keputusan Menteri Lingkungan Hidup (KMLH) No. 51 Tahun 2004. Baku Mutu Air Laut Untuk Biota. Jakarta

Khouw, A S. (2016). Metode Dan Analisa Kuantitatif Dalam Bioekologi Laut. Alfabeta. Bandung.

Mason, J. 1981. Biology of Coastal Water A System Approach. Blackwell Scientific Publication, London, 183-209 pp.

Mentungun, J., Juliana dan M.Y. Beruatjaan. (2011). Kelimpahan Gastropoda pada Habitat Lamun di Perairan Teluk Un Maluku Tenggara. Prosiding Seminar Nasional : Pengembangan Pulau-Pulau Kecil 2011. ISBN : 978-602-98439-2-7. Hal : 225-231.

Natan, J dan Khouw, S.A. (2002). Studi Komparatif Struktur Komunitas Limpet Pada Zona Intertidal Pantai Berbatu Desa Oma, Pulau Haruku dan Desa Ohoiwait, Pulau Kei Besar. Ichthyos. Fakultas Perikanan, Universitas Pattimura, Ambon.

Nontji, A. (2002). Laut nusantara. Penerbit djambatan. Jakarta.

Odum, E. P. (1971). Foundamental of Ecological. W. B. Sounders Company. Philadelphia.

Odum, E. P. (1983). Dasar-dasar Ekologi. Edisi ketiga. Yogyakarta: Gajah Mada University, press.

Oliver, A.P.H. (2004). Philip's Guide to Seashelss of the world. Publisher: Firefly book LTD. Ontario, Canada.

Pratama, Surya Widya. (2018). Indeks Pencemaran Air Laut Pantai Selatan Bantul Dengan Parameter TSS dan Kimia Non-Logam. Skripsi. Yogyakarta. 
Rasyid, F. (2001). Sebaran dan Asosiasi Makroinfauna pada Ekosistem Padang Lamun di Perairan Teluk Harun, Teluk Lampung, Lampung Selatan. Skripsi. Fakultas Perikanan dan Ilmu Kelautan Institut Pertanian Bogor : Bogor.

Romimohtarto, K dan Juwana Sri. (2001). BiologI Laut: Ilmu Pengetahuan tentang Biologi Laut. Penerbit Djambatan, Jakarta.

Satria, M. (2014). Keanekaragaman dan Distribusi Gastropoda di Perairan Desa Berakit Kabupaten Bintan. Skripsi. Fakultas Kelautan dan Perikanan. UMRAH. Tanjung pinang.

Soegianto, A., (1994). Ekologi Kuantitaif Metode Analisis Populasi dan Komunitas. Penerbit Usaha Nasional. Surabaya, Indonesia.

Tomascik,T.A.J.Mah; A Nontji and M. K.Moosa. (1997). The ecology of the Indonesian seas. Part two. Published by periplus editions (HK) Lid. Singapore. 